\title{
Dinoflagellates in a mesotrophic, tropical environment influenced by monsoon
}

\author{
Priya M. D’Costa, Arga Chandrashekar Anil*, Jagadish S. Patil, Sahana Hegde, \\ Maria Shamina D’Silva, Molji Chourasia
}

National Institute of Oceanography, Dona Paula, Goa 403 004, India

*Corresponding author. Tel.:091-832-2450404; fax: 091-832-2450704;

E-mail: acanil@nio.org 


\begin{abstract}
The changes in dinoflagellate community structure in both - the water column and sediment in a mesotrophic, tropical port environment were investigated in this study. Since the South West Monsoon (SWM) is the main source of climatic variation, observations were made during two consecutive post-monsoon periods (2001 and 2002) and an intervening pre-monsoon period (2002). The pre-monsoon period supported a more diverse dinoflagellate community in the water column compared to both post-monsoon periods. Heterotrophic dinoflagellates were abundant in the water column as well as sediment. A seasonal cycling between vegetative and resting cysts of autotrophic and heterotrophic dinoflagellates governed by the environmental characteristics of the study area was observed. Temperature, salinity and suspended particulate matter were the main factors affecting dinoflagellate community structure in both the water column and sediment. The dominant dinoflagellates in the water column differed during both post-monsoon periods that followed two dissimilar monsoon events. Prorocentroids and gonyaulacoids dominated the water column subsequent to the 2001 SWM, whereas dinophysoids and unidentified tiny dinoflagellates dominated during the next post-monsoon period. The 2001 SWM started in May, peaked during June-July and reduced gradually to end in October. The 2002 SWM was erratic; it started late (in June) and ended earlier (in September). These observations highlight the potential of the SWM to influence the community structure of dinoflagellates in tropical waters and points to the importance of long-term studies to discern robust variations in dinoflagellate communities in response to fluctuating monsoon regimes.
\end{abstract}

Keywords: dinoflagellates; seasonal cycling; heterotrophy; monsoons; tropical environment 


\section{Introduction}

Harmful algal blooms (HABs) are a cause of concern worldwide. Over the years, there has been a marked increase in their occurrence along with their spread to new geographical regions (Anderson et al. 2002a). The apparent global expansion of HABs is linked with increased anthropogenic eutrophication of coastal waters and increased load of nutrients (Hallegraeff 1993; Anderson et al. 2002a).

This study provides an insight into the dinoflagellate community in the sediment and the overlying water column in the ports of Mumbai, along the west coast of India. The study area is subjected to increasing anthropogenic pressure and is characterized as mesotrophic with regard to nitrate concentration. Over the years, a gradual increase in nitrate concentration along with a simultaneous decrease in dissolved oxygen (DO) has been observed. Characterization based on Assessment of Estuarine Trophic Status (ASSETS) model (Bricker et al. 2003) indicates that the current status is poor and the environment is degrading (Sawant et al. 2007).

The South West monsoon (SWM) from June to September is the main source of climatic variation in the study area. It leads to considerable input of nutrients through precipitation and terrigenous sources. Physical or chemical perturbations are suggested to disrupt biological controls opening 'loopholes' into which some species can explode (Bakun and Broad 2003). The SWM may act as a similar interruptive influence producing 'loopholes' that allow drastic changes in phytoplankton community structure. Taking these factors into consideration, this study elucidates the modulations in dinoflagellate community in benthic and pelagic habitats and attempts to determine the response of the dinoflagellate community to monsoon-influenced seasonal changes.

\section{Materials and methods}

\subsection{Study area}

Mumbai and Jawaharlal Nehru Ports are situated in Mumbai along the west coast of India, just south of the tropic of cancer $\left(18^{\circ} 54^{\prime} \mathrm{N}\right.$ latitude, $72^{\circ} 40^{\prime} \mathrm{E}$ longitude) (Fig. 1). Both these ports together form a semi-enclosed basin, which opens into the Arabian Sea at its southwesterly side. The basin receives a considerable amount of wastewater from industries and domestic waste. 


\section{2. $\quad$ Sampling strategy}

Sampling was carried out in November 2001 (post-monsoon I), May (pre-monsoon) and October-November 2002 (post-monsoon II) in Mumbai and Jawaharlal Nehru Ports. 33 stations were selected so as to include berths, ferry wharves, spoil grounds and ship breaking areas. Among these, sediment samples were collected at 22 stations for dinoflagellate cysts. For phytoplankton, surface and near bottom waters were sampled at these stations wherever possible in addition to some adjoining areas (total 30 stations). 3 stations (31-33) are located offshore $\left(18^{\circ} 47^{\prime} \mathrm{N}, 72^{\circ} 49^{\prime} \mathrm{E} ; 18^{\circ} 52^{\prime} \mathrm{N}, 72^{\circ} 43^{\prime} \mathrm{E} ; 18^{\circ} 57^{\prime} \mathrm{N}, 72^{\circ} 49^{\prime} \mathrm{E}\right)$ and are not shown in the figures.

\subsection{Sediment sampling, processing and microscopy}

Sediment samples were collected, in triplicate, using $20 \mathrm{~cm}$ long PVC cores with an inner diameter of $2.5 \mathrm{~cm}$. During the first sampling, core samples were collected by divers. But due to low light levels in the port waters and visibility problems faced by divers, a modified van Veen grab with a grabbing area of $0.04 \mathrm{~m}^{2}$ was used during the second and third sampling. The grab was equipped with flaps on the top side which allowed collection of undisturbed sediment cores. Cores were sealed with airtight caps and stored in the dark at $4^{\circ} \mathrm{C}$ until analysis.

After transportation to the laboratory, sediment cores were sectioned at $2 \mathrm{~cm}$ intervals, mixed well and stored in airtight plastic bags at $4^{\circ} \mathrm{C}$ in the dark. The $0-2 \mathrm{~cm}$ core sections were palynologically processed (Matsuoka and Fukuyo 2000). $0.25-1.0 \mathrm{~mL}$ aliquots of the refined sample was diluted to a total volume of $2.5 \mathrm{ml}$ in a transparent petridish $(3.8 \mathrm{~cm}$ diameter), mixed well and placed on the microscope stage. After a settling period of 10 minutes, the entire petridish was scanned using an inverted Olympus IX71 microscope, with phase contrast attachment, at 100 and 200 times magnification. Depending on the volume of the aliquot, the refined sample was counted in duplicate or higher number of replicates such that a total of $1 \mathrm{~mL}$ of refined sample was analyzed. Dinoflagellate cysts were identified based on the available literature (Wall and Dale, 1968; Bolch and Hallegraeff, 1990; Bolch et al. 1991; Hallegraeff et al. 1991; Lewis, 1991; Kokinos and Anderson 1995; Yu-zao et al. 1996; Nehring, 1997; Sonneman and Hill, 1997; Godhe et al. 2001; Matsuoka and Fukuyo, 2000). Dinoflagellate cyst

abundance was expressed as number of cysts $\mathrm{g}^{-1}$ dry sediment. The water content was calculated 
according to the formula given by Matsuoka and Fukuyo (2000). Due to the low abundance of cysts encountered, germination experiments were not carried out.

\subsection{Water sampling}

Surface and near bottom water samples (1 L) were collected using a bucket and Niskin sampler respectively. The samples were immediately fixed with Lugol's iodine, allowed to stand undisturbed for 48 hours and concentrated to $250 \mathrm{~mL}$ by siphoning off the surface waters with a plastic tubing covered with a $20 \mu \mathrm{m}$ mesh to avoid loss of phytoplankton cells. Care was taken not to disturb the minimum settled volume. Aliquots of $2.5 \mathrm{~mL}$, in triplicate, were dispensed in a transparent petridish (3.8 cm diameter), mixed well and placed on the microscope stage. After a settling period of 10 minutes, the entire petridish was scanned using an inverted microscope, at 100 and 200 times magnification. Phytoplankton were identified based on the available literature (Subrahmanyan, 1946; Desikachary, 1987; Tomas, 1997; Horner, 2002) and expressed as cells L'

1. Dinoflagellates, $<25 \mu \mathrm{m}$, which could not be identified upto generic level, were grouped together as Unidentified Tiny Dinoflagellates (UTDs).

Temperature, $\mathrm{pH}$, suspended particulate matter (SPM), salinity, nutrients, DO and bacteria were analyzed following standard procedures and are published elsewhere (Sawant et al. 2007). The relevant data is considered here. DO saturation values indicated respiration-dominated waters during post-monsoon I and production-dominated waters during pre-monsoon. During post-monsoon II, surface waters were respiration-dominated whereas near bottom waters were production-dominated. During pre-monsoon, temperature $\left(30^{\circ} \mathrm{C}\right.$; an increase of $\left.2^{\circ} \mathrm{C}\right)$, salinity, SPM and bacterial abundance increased whereas concentration of nitrite $\left(\mathrm{NO}_{2}-\mathrm{N}\right)$, phosphate $\left(\mathrm{PO}_{4}-\mathrm{P}\right)$ and silicate $(\mathrm{Si})$ decreased sharply. Concentration of nitrate $\left(\mathrm{NO}_{3}-\mathrm{N}\right)$, however, was comparable to post-monsoon values (details in Fig. 6). $\mathrm{pH}$ values ranged between 7.5 and 8.1 in surface and near bottom waters.

\subsection{Data analyses}

Dinoflagellate abundance was converted into a lower triangular similarity matrix using BrayCurtis coefficients (Bray \& Curtis 1957) and subjected to clustering and ordination techniques using the software PRIMER (version 5). Univariate measures [Shannon-Wiener diversity index (H'), Margalef's species richness (d) and Pielou's evenness (J')] were analyzed using PRIMER 
(version 5) and the variations in these determined by one-way ANOVA. One-way ANOVA was also performed on log-transformed dinoflagellate abundance to evaluate spatial and temporal variation (Sokal and Rohlf 1981). Spatial variation in the dinoflagellate community and the contribution of individual taxa to the dinoflagellate community are presented as SURFER plots using SURFER 6 and 7 programs. Canonical Correspondence Analysis was performed to evaluate the relationships between environmental variables and dinoflagellates (vegetative cells and cysts) (ter Braak, 1995) using the Multi-Variate Statistical Package program version 3.1(Kovach, 1998).

Dinoflagellates were classified into autotrophic and heterotrophic forms based on the presence/absence of chloroplasts. They were also classified into groups based on the order to which they belong.

\section{Results}

\subsection{Dinoflagellate cyst community}

Dinoflagellate cyst abundance varied from 36 - 262 cysts $\mathrm{g}^{-1}$ dry sediment during the entire study period. 32 species belonging to 15 genera (Fig. 2; Table 1) were recorded. Heterotrophic cysts were observed at all stations and contributed $23-97 \%$ of the cyst population. Protoperidinium spp. was the most dominant heterotrophic dinoflagellate, followed by Polykrikos spp. (data not shown).

\subsection{Planktonic dinoflagellate community}

117 species of phytoplankton belonging to 48 genera were recorded with abundance ranging from $2 \times 10^{2}-1.2 \times 10^{6}$ cells L ${ }^{-1}$ (D'Costa, P. M., et al. unpubl). 28 dinoflagellate species were observed (Table 2) with abundance between $0-8.7 \times 10^{4}$ cells $\mathrm{L}^{-1}$ in surface waters and $0-8 \mathrm{x}$ $10^{2}$ cells $\mathrm{L}^{-1}$ in near bottom waters. Dinoflagellates were more abundant in surface waters (5$24 \%$ of the phytoplankton community) compared to near bottom waters (1-2\%) (data not shown). 


\subsection{Spatial variation}

\subsubsection{Post-monsoon I}

During post-monsoon I, dinoflagellate cyst abundance was highest (262 cysts gm $^{-1}$ dry sediment) at station 30, the shipping channel in the bay (Fig. 3g). Cluster analysis of the dinoflagellate cyst community revealed 3 groups and 2 dissimilar stations at $50 \%$ Bray-Curtis similarity level (Fig. 4g) that were dominated by Gonyaulax spinifera, Protoperidinium pentagonum and Protoperidinium sp. (data not shown). Dinoflagellate abundance ranged from 0 $-8 \times 10^{3}$ cells $\mathrm{L}^{-1}$ in surface waters with very high abundance of Gonyaulax sp. $\left(8.7 \times 10^{4}\right.$ cells L1) recorded at station 15, a shallow station (Fig. 3a; Table 1). In near bottom waters, dinoflagellates were observed at fewer stations and at lower abundance $\left(0-8 \times 10^{2}\right.$ cells $\left.\mathrm{L}^{-1}\right)$ (Fig. 3d) compared to surface waters. Cluster analysis of the vegetative dinoflagellate community indicated most of the stations to be similar at 50\% Bray-Curtis similarity level (Fig. 4a,d). This is evident in surface waters (Fig. 4a) where all the stations (except station 21 with the lowest dinoflagellate abundance) clustered together. In near bottom waters, cluster analysis revealed 3 groups and 1 dissimilar station (Fig. 4d). Prorocentrum micans dominated the grouped stations in surface and near bottom waters (data not shown).

\subsubsection{Pre-monsoon}

During pre-monsoon, highest dinoflagellate cyst abundance (224 cysts gm $^{-1}$ dry sediment) was observed at station 30 (Fig. 3h). Cluster analysis of the dinoflagellate cyst community indicated 3 groups and 3 dissimilar stations at 50\% Bray-Curtis similarity level (Fig. 4h) that were dominated by Gonyaulax scrippsae, G. spinifera, Protoceratium reticulatum, Protoperidinium leonis and Pyrophacus steinii (data not shown). Dinoflagellate abundance ranged from $0-9 \times 10^{2}$ cells $\mathrm{L}^{-1}$ in surface waters and $0-2 \times 10^{2}$ cells $\mathrm{L}^{-1}$ in near bottom waters. High abundance of Protoperidinium pellucidum $\left(4.5 \times 10^{4}\right.$ cells $\left.\mathrm{L}^{-1}\right)$ was recorded in surface waters at station 6 (Fig. 3b). Near bottom waters were not sampled at this station. Cluster analysis of the vegetative dinoflagellate community revealed 4 groups and 11 dissimilar stations in surface waters and all dissimilar stations in near bottom waters at 50\% Bray-Curtis similarity level (Fig. 4b,e). Prorocentrum micans and Protoperidinium sp. dominated the grouped stations (in surface waters). The dissimilar stations were dominated by Dinophysis caudata, Dinophysis 
spp., Dissodium asymmetricum, Gonyaulax sp., Gotoius abei, Prorocentrum micans, Protoperidinium divergens, P. leonis, P. pedunculatum, P. pellucidum, P. pentagonum and P. steinii (data not shown).

\subsubsection{Post-monsoon II}

During post-monsoon II, dinoflagellate cyst abundance was highest (197 cysts gm $^{-1}$ dry sediment) at station 2. Station 30 showed moderate dinoflagellate cyst abundance (131 cysts gm ${ }^{-}$

${ }^{1}$ dry sediment) (Fig. 3i). Cluster analysis of the cyst community revealed 3 groups at 50\% BrayCurtis similarity level (Fig. 4i) that were dominated by Gonyaulax scrippsae, G. spinifera and Protoperidinium leonis (data not shown). Dinoflagellate abundance ranged from $0-1 \times 10^{3}$ cells $\mathrm{L}^{-1}$ in surface waters and $0-1.5 \times 10^{2}$ cells $\mathrm{L}^{-1}$ in near bottom waters. Highest dinoflagellate abundance in surface waters was recorded at station $6\left(0-1 \times 10^{3}\right.$ cells $\left.\mathrm{L}^{-1}\right)$, followed by station $27\left(0-9 \times 10^{2}\right.$ cells $\left.\mathrm{L}^{-1}\right)$ (Fig. $\left.3 \mathrm{c}\right)$. Cluster analysis of the vegetative dinoflagellate community indicated that most of the stations in surface waters were similar at 50\% Bray-Curtis similarity level. With the exception of station 12 that had lowest abundance, all other stations clustered together (Fig. 4c). Near bottom waters were characterized by 4 groups and 3 dissimilar stations (Fig. 4f). Dinophysis acuta, D. caudata, D. norvegica and UTDs were the most dominant dinoflagellates at the grouped stations, followed by Ceratium furca and C. fusus (data not shown).

\subsection{Temporal variation}

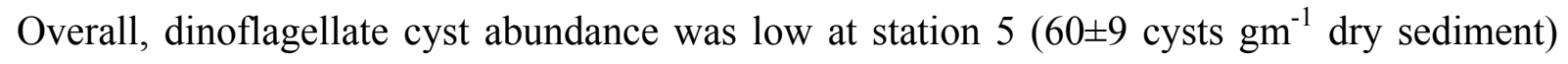
whereas moderate to high abundance was recorded at stations 4, 24 and $30(162 \pm 54,155 \pm 63$ and $206 \pm 67$ cysts gm $^{-1}$ dry sediment respectively). One-way ANOVA indicated significant temporal variation in the abundance $(\mathrm{N}, \mathrm{p} \leq 0.01)$, Margalef's species richness $(\mathrm{d}, \mathrm{p} \leq 0.001)$ and ShannonWiener diversity $\left(\mathrm{H}^{\prime}, \mathrm{p} \leq 0.005\right)$ of the dinoflagellate cyst community. Heterotrophic dinoflagellate cysts (mainly peridinioids) dominated during both post-monsoon periods whereas autotrophic (mainly gonyaulacoids) and heterotrophic dinoflagellate cysts were equally dominant during pre-monsoon (Fig. 5).

Abundance, species richness, diversity and Pielou's evenness of the vegetative dinoflagellate community in surface and near bottom waters did not show significant temporal variation (data 
not shown). Most stations clustered together during both post-monsoon periods (Fig. 4a,c,d,f), with autotrophic dinoflagellates emerging as the dominant group (Fig. 5). The pre-monsoon period was characterized by higher number of dissimilar stations (Fig. 4b,e) that supported diverse dinoflagellate communities. Heterotrophic dinoflagellates (mainly peridinioids) dominated the water column during this period (Fig. 5). Ceratians were restricted to the postmonsoon periods with the exception of $C$. furca that was recorded in surface waters during premonsoon (Table 3).

A characteristic seasonal cycling was observed for peridinioids. They were the dominant dinoflagellate cysts $(64 \%)$ during post-monsoon I and contributed $13 \%$ and $21 \%$ of the vegetative dinoflagellate community in surface and near bottom waters respectively. During premonsoon, peridinioid cysts decreased to $49 \%$ whereas relative abundance of peridinioids in the water column increased to 54\% (surface) and 56\% (near bottom waters). During the next postmonsoon period, the peridinioids in the water column switched back to post-monsoon I levels (upto $15 \%$ and $39 \%$ respectively) with corresponding increase in their cyst abundance (67\%) (Fig. 5).

Post-monsoon I and post-monsoon II were dominated by different dinoflagellates. Prorocentroids and gonyaulacoids predominated during post-monsoon I whereas dinophysoids and UTDs predominated during post-monsoon II. UTDs were higher in near bottom waters (39\% of the vegetative dinoflagellate community) compared to surface waters (19\%) during post-monsoon II (Fig. 5).

\subsection{Effect of environmental variables on vegetative cells and cysts of dinoflagellates}

CCA station and species biplots were plotted separately for vegetative dinoflagellates in surface and near bottom waters and for dinoflagellate cysts in sediment (Fig. 7a-c). 3 and 5 axes were extracted for vegetative dinoflagellates and dinoflagellate cysts respectively.

In the CCA biplot for surface waters (Fig. 7a), the 3 axes explained $67 \%$ of the relationship between vegetative dinoflagellates and environmental variables. Temperature, salinity, SPM and oxygen saturation were the most important environmental variables influencing dinoflagellate community structure in surface waters. 2 groups were discerned among the vegetative dinoflagellates. Group I encompassed a diverse assemblage of dinoflagellates (mainly 
heterotrophic forms) and showed preference for elevated temperature, salinity and SPM and lower concentrations of nutrients. Most of these species dominated in the pre-monsoon period, characterized by the above environmental conditions. Group II consisted of species that preferred low temperature, salinity and SPM and elevated concentrations of nutrients. These species dominated in both post-monsoon periods. Species located in the upper half of the biplot in both Groups I and II were related to higher values of oxygen saturation whereas the reverse was true for the species located in the lower half of the biplot. The seasonal variation in the dinoflagellate community in surface waters, evident in the species biplot, was confirmed by the clustering pattern of stations in the accompanying station biplot. However, some dissimilar stations were noticed. These included stations 2, 8, 11 and 30 during the post-monsoon II period (that clustered together) and stations 11 and 13 during the pre-monsoon period. Minute thecate dinoflagellates (Alexandrium and Gonyaulax) were recorded at only the above mentioned stations during the post-monsoon II and pre-monsoon sampling resulting in these stations being dissimilar from the rest. In addition, station 31 sampled during the post-monsoon II period was located close to the pre-monsoon stations cluster and supported only UTDs.

In the CCA biplot for near bottom waters (Fig. 7b), the 3 axes explained $70 \%$ of the relationship between vegetative dinoflagellates and environmental variables. Temperature, salinity, nitrate and SPM were the most important environmental variables influencing dinoflagellate community structure in near bottom waters. 3 groups were recognized among the vegetative dinoflagellates. Group I dinoflagellate species dominated in post-monsoon I and premonsoon periods. These species were favoured by lower values of temperature, SPM, nitrate and phosphate. Group II, the largest group, consisted of the most dominant species in the premonsoon period. These species preferred elevated conditions of temperature, salinity, SPM, nitrate and phosphate. The third group (Group III) consisted of the dominant species in postmonsoon II sampling. This group preferred high concentration of nitrite and low values of salinity. The seasonal trend observed in the species biplot was further confirmed by clustering together of stations sampled during each sampling period at distinct points in the station plot.

In the CCA biplot for dinoflagellate cysts (Fig. 7c), the 5 axes explained $83 \%$ of the relationship between dinoflagellate cysts and environmental variables. Salinity, SPM, temperature and organic carbon were the most important environmental variables influencing 
dinoflagellate cyst community structure in sediment. Majority of the dinoflagellate cyst species were located near the centre of the ordination diagram indicating that these species were not associated with any particular environmental variable. However, some autotrophic species (Gonyaulax digitalis, Lingulodinium polyedrum and Protoceratium reticulatum) showed preference for high values of salinity and SPM, conditions prevalent during the pre-monsoon period, as indicated in the accompanying station biplot. A distinct difference between the three sampling periods is clear in the station biplot. The position of 2 heterotrophic species (Lebouraia cf. minuta and Zygabikodinium lenticulatum) in the species biplot correlated with the post-monsoon I and post-monsoon II periods respectively.

\section{Discussion}

The dinoflagellate cyst abundance recorded in the study area (36 - 262 cysts $\mathrm{g}^{-1}$ dry sediment) is less than that reported from other areas [in the range of a few thousand cysts $\mathrm{g}^{-1}$ dry sediment] (refer Cho and Matsuoka 2001 and references therein). Along the southwest coast of India, Godhe et al. (2000) reported presence of 27 dinoflagellate cysts; however, dinoflagellate abundance at only 1 station (122 cysts $\mathrm{g}^{-1}$ dry sediment) was provided. Patil, J. S. (unpubl.) reported average cyst abundance of $150-570$ cysts $\mathrm{g}^{-1}$ wet sediment (23 species) in the Zuari estuary, Goa. Compared to these reports, Polykrikos cf. kofoidii and Pyrodinium cf. bahamense (refer Fig. 2) are the additional species reported in this study.

Abundance of heterotrophic dinoflagellate cysts, as observed in the study area, suggests nutrient-rich conditions and abundance of prey organisms (Harland et al. 2006). Cysts of Protoperidinium followed by Polykrikos were the most abundant heterotrophic forms. Dominance of different heterotrophic taxa reflects different nutrient levels based on their feeding mechanisms (Matsuoka et al. 2003). However, Dale (2001) reported that increased proportion of heterotrophic dinoflagellate cysts may result from reduced production of autotrophic cysts. Thus, for the increase in proportion of heterotrophic dinoflagellate cysts to be considered robust signals of elevated nutrient conditions, there should also be an accompanying increase in the abundance (cysts $\mathrm{g}^{-1}$ dry sediment) of heterotrophic dinoflagellate cysts. As this is the first detailed study of dinoflagellate cysts in this region, we do not have any earlier data for comparison purposes. 
Abundance, species richness, diversity and Pielou's evenness of both - cyst and vegetative stages of dinoflagellates, did not vary significantly among stations during each of the 3 sampling periods (data not shown). No correlation between dinoflagellate cyst abundance and sediment texture characteristics was observed. Cluster analysis of the dinoflagellate cyst communities during each of the three sampling periods showed that stations merging together at $50 \%$ similarity level were located at different sites in the study area, indicating that dinoflagellate cyst assemblages were not unique to particular microenvironments. However, changes in clustering patterns of stations were observed with respect to dinoflagellates in surface and near bottom waters (Figs. 4a-f). Dinoflagellate assemblages in the overlying water column were similar at most stations during both post-monsoon periods. The pre-monsoon period supported a more diverse assemblage of dinoflagellates, which was reflected in highest values of species richness and diversity observed during this period (data not shown). These trends were evident even in near bottom waters characterized by limited but diverse occurrence of dinoflagellates (Fig. 4d,f).

The seasonal changes in dinoflagellate community structure in sediment and the overlying water column, as evident from the present data set, is outlined in Fig. 6. While the cyst population had consistent domination of heterotrophs (mainly Protoperidinium spp.) with autotrophic dinoflagellate cysts being equally dominant during pre-monsoon, the water column oscillated between autotrophic (post-monsoon) and heterotrophic dinoflagellate dominance (premonsoon). Most of the autotrophic dinoflagellates recorded in the water column (Prorocentrum, Ceratium and Dinophysis spp.) are non-cyst forming dinoflagellates and capable of mixotrophy. Mixotrophy is an important adaptation to life in planktonic habitats and increases access to growth-limiting nutrients, carbon and other growth factors. Mixotrophic organisms can sustain growth when mixed out of the euphotic zone by switching to phagotrophy. However, mixotrophic dinoflagellates survive better than heterotrophic dinoflagellates during periods of reduced particulate food, despite their low predation rates due to their ability to photosynthesize (Jost et al. 2004 and references therein). Such seasonal cycling patterns between benthic and pelagic domains are clearly evident in peridinioids (Fig.5) and indicate a possible annual cycling for this group of dinoflagellates. However, species-specific differences were observed in the peridinioids recorded in the water column and sediment. The Protoperidinium spp. recorded in the water column were not necessarily represented in sediment (in cyst form) and vice-versa (Tables 1, 2). 
The trends observed in the occurrence of mixotrophic dinoflagellates during the three sampling periods is probably linked to changes in environmental variables as well as grazing pressure in the study area. The water column was respiration-dominated during post-monsoon I and production-dominated during pre-monsoon. During pre-monsoon, there was a decrease in concentrations of nitrite, phosphate and silicate along with an increase in temperature, $\mathrm{pH}$, salinity, SPM and bacterial abundance. These changes were associated with decrease in mixotrophic dinoflagellates and increased dominance of heterotrophic dinoflagellates in the water column. Mixotrophic dinoflagellates (considered 'generalists' in this particular premonsoon scenario) are less efficient in converting food to energy. Heterotrophic dinoflagellates, considered 'specialists' due to their mode of nutrition, proliferate under these conditions. These changes were also reflected in the zooplankton population in the study area. During premonsoon, purely herbivorous copepods like Nanocalanus minor, Paracalanus sp. and Temora discaudata decreased in abundance whereas carnivorous copepods like Tortanus barbatus and omnivorous forms like Centropages furcatus, Oithona sp., Corycaeus sp, were comparatively more abundant (Gaonkar, C. et al. under review).

The effect of environmental variables on cyst and vegetative stages of dinoflagellates is clearly revealed in the canonical correspondence analysis (Fig. 7). Temperature, salinity and SPM were the crucial variables affecting dinoflagellate community structure in both the water column as well as sediment. Temperature, salinity, and light availability affect germination of dinoflagellates cysts (Kremp and Anderson, 2000) and thus the seasonal cycling between benthic and pelagic domains. SPM not only reduces light penetration but also affects distribution of dinoflagellates in the water column and sediment through sediment resuspension. Several groups could be recognized among the vegetative and cyst dinoflagellate communities. These groups favoured particular ranges of environmental variables that were characteristic of the sampling periods, indicating the temporal variation in dinoflagellate communities in the study area. The high diversity of dinoflagellate communities in the water column during the premonsoon period is clear in the CCA biplots, confirming the results obtained by NMDS analysis.

The differences in dominant dinoflagellates in the water column during both post-monsoon periods (prorocentroids and gonyaulacoids during post-monsoon I; dinophysoids and UTDs during post-monsoon II; Fig. 5) are markedly evident in the CCA biplot for near bottom waters 
and reflect the possible influence of the preceeding SWM, the main source of climatic variation in the study area. The SWM is characterized by drastic increase in turbulence and water mixing. Small scale turbulence can have deleterious effects on dinoflagellates by mechanical damage to cell integrity, by influencing physiological processes such as cell division, and by disorientating the organisms and interfering with their migration (White, 1976). During the sampling period, there were differences in the duration and intensity of the SWM. In 2001, the monsoon was prolonged. It started in May, peaked during June-July and ended in October. However, the 2002 monsoon was erratic; it started in June and ended in September (Fig. 8).

Dinophysoids and UTDs were the dominant dinoflagellates in the post-monsoon II period subsequent to the erratic 2002 SW monsoon. They were associated with low values of temperature, salinity and SPM and high nutrient concentrations in surface waters. In near bottom waters, they preferred low salinity and high concentration of nitrite, reduced form of nitrogen. Dinophysis spp. are associated with thermal (Delmas et al. 1992) and salinity-induced stratifications (Godhe et al. 2002). However, Nishitani et al. (2005) have recorded maximum cell densities of Dinophysis spp. in Mutsu Bay immediately after a storm-induced mixing event. These organisms are able to migrate through strong gradients as well and survive for long periods under unfavourable conditions (Setala et al. 2005). UTDs, the other dominant dinoflagellates in the post-monsoon II period were more abundant in near bottom waters (39\% of the vegetative dinoflagellate community) compared to surface waters $(19 \%)$. This feature is consistent with the higher DO saturation levels in near bottom waters (production-dominated) compared to surface waters (respiration-dominated) during the post-monsoon II period (Fig. 6). This was contrary to the trend observed during post-monsoon I. In addition, the observations carried out during the Global Ballast Water Management Program indicated that bacterial abundance was also low compared to post-monsoon I (Fig. 6). A marked difference in the biomass and abundance of zooplankton during both post-monsoon periods was also observed. Species-specific differences in the copepod population were noticed. Microsetella sp. and Oncea sp. were absent during post-monsoon I whereas Acartia centrura and Nanocalanus sp. were absent during post-monsoon II (Gaonkar, C. et al. under review).

The differences in dominant dinoflagellate groups during the two post-monsoon periods indicates the effect of the preceeding SW monsoon. However, though dinoflagellates exhibit 
particularly strong responses to turbulence, its effects are difficult to separate from factors like nutrients and light (Estrada and Berdalet, 1998). Smayda and Reynolds (2003) have classified dinoflagellates into C-, S- and R- strategists based on their response to light energy, nutrient supply and physical mixing. C-strategists (colonist species that predominate in chemically disturbed habitats), S-strategists (nutrient stress-tolerant species) and R-strategists (tolerant of shear/stress forces in physically disturbed water masses). R-strategist dinoflagellates include Alexandrium tamarense, some Ceratium spp., Gymnodinium breve, Gymnodinium catenatum, Gymnodinium mikimotoi [renamed Karenia mikimotoi (Daugbjerg et al. 2000)], Lingulodinium polyedrum and Pyrodinium bahamense var. compressum (Smayda and Reynolds 2001), most of which have been recorded at low concentrations in sediment in the study area. Gymnodinioids, with sizes $<50 \mu \mathrm{m}$, tend to withstand turbulence well (Sullivan and Swift 2003) and may be favoured under such conditions. Since they commonly occur in ballast and port sediments, they are regarded as potential bloom-formers (Pertola et al. 2006). However, in the present study area, they contribute very less to the cyst community (max. 2.14\%) and are not observed in the water column. Currently, the cyst community is dominated by gonyaulacoid and peridinioid dinoflagellates whereas the water column sustains gonyaulacoids, peridinioids, dinophysoids and UTDs.

'Loopholes' in biological control mechanisms (due to physical or chemical perturbations) are suggested as the cause for the high yield of the Peru-Humboldt current fisheries in comparison with the other Eastern Boundary Current systems (Benguela, Canary and California currents) (Bakun and Broad 2003). Irigoien et al. (2005) have extended this mechanism to interpret blooming conditions as physical or chemical perturbations disrupting the predator-prey controls that normally operate at the level of the microbial loop, opening 'loopholes' into which some phytoplankton species populations can explode. In this context, the SWM probably acts as an environmental perturbation that loosens some biological controls (in this case, bacterial abundance and copepod population) resulting in emergence of opportunistic species. Such effects of the SWM on the dinoflagellate community are significant in view of the rising trends in the frequency and magnitude of extreme rain events observed over central India from 1951 to 2000 (Goswami et al. 2006) and the increase in the Asian SWM during the last four centuries in response to global climate change (Anderson et al. 2002b). 
This study, inclusive of three sampling events and spanning a period of two years, provides an overview of the dinoflagellate community in surface and near bottom waters and sediment in a tropical environment. It describes the seasonal cycling between pelagic and benthic domains, the potential of the SWM to effect changes in the dinoflagellate community and points to the necessity of long-term surveys (inclusive of several monsoon events) to discern robust patterns in dinoflagellate communities. Inclusion of sediment trap methodologies will provide information on life history cycles and reproductive strategies of cyst-forming dinoflagellates (Montresor et al. 1998). This is crucial in case of naked vegetative dinoflagellates that would otherwise be degraded by the preservative used (Lugol's iodine) and calcareous dinoflagellate cysts, whose calcium carbonate spines dissolve during the palynological procedures used for treating sediment samples. Such long-term studies would provide a comprehensive picture of the dinoflagellate community in tropical environments, its regulating factors and explain the modulations in community structure in response to fluctuating SWM regimes.

\section{Acknowledgements}

We are grateful to Dr. S.R. Shetye, Director of the National Institute of Oceanography, for his support and encouragement. We acknowledge Dr. Fukuyo and his team for help and advice in identifying dinoflagellate cysts. We thank Prof. Cajo ter Braak for his advice and suggestions regarding CCA analysis. We thank Dr. N.B. Bhosle for his constant encouragement. We thank Dr. S. S. Sawant for his help during this investigation. We gratefully acknowledge Mr. K. Venkat for his ever-willing help during the period of this work right upto preparation of the final manuscript. We also thank our colleagues for their suggestions. The efforts of the anonymous reviewers have helped in improving the quality of the manuscript and are appreciated. This data was collected as part of the Global Ballast Water Management Program initiative in India. P.M.D. acknowledges the Research Fellowship provided by the Council of Scientific and Industrial Research (CSIR) (India). This is a NIO contribution No. \#\#\# 


\section{References}

Anderson, D.M., Glibert, P.M., Burkholder, J.M., 2002a. Harmful algal blooms and eutrophication: nutrient sources, composition and consequences. Estuaries 25, 704-726.

Anderson, D.M., Overpeck, J.T., Gupta, A.K., 2002b. Increase in the Asian Southwest monsoon during the past four centuries. Science 297, 596-599.

Bakun, A., Broad, K., 2003. Environmental 'loopholes' and fish population dynamics: comparative pattern recognition with focus on El Nino effects in the Pacific. Fisheries Oceanography 12, 458-473.

*Bolch, C.J., Hallegraeff, G.M., 1990. Dinoflagellate cysts in recent marine sediments from Tasmania, Australia. Botanica Marina 33, 173-192.

*Bolch, C.J., Blackburn, S.I., Cannon, J.A., Hallegraeff, G.M., 1991. The resting cyst of the redtide dinoflagellate Alexandrium minutum (Dinophyceae). Phycologia 30, 215-219.

Bricker, S.B., Ferreira, J.G., Simas, T., 2003. An integrated methodology for assessment of estuarine trophic status. Ecological Modelling 169, 39-60.

Cho, H-J., Matsuoka, K., 2001. Distribution of dinoflagellate cysts in surface sediments from the Yellow Sea and East China Sea. Marine Micropaleontology 42, 103-123. 
Dale, B., 2001. Marine dinoflagellate cysts as indicators of eutrophication and industrial pollution: a discussion. The Science of the Total Environment 264, 235-240.

Daugbjerg, N., Hansen, G., Larsen, J., Moestrup, Ø., 2000. Phylogeny of some of the major genera of dinoflagellates based on ultrastructure and partial LSU rDNA sequence data, including the erection of three new genera of unarmoured dinoflagellates. Phycologia 39, 302317.

Delmas, D., Herbland, A., Maestrini, S.Y., 1992. Environmental conditions which lead to increase in cell density of the toxic dinoflagellates Dinophysis spp. in nutrient-rich and nutrient-poor waters of the French Atlantic coast. Marine Ecology Progress Series 89, 53-61.

Desikachary, T.V., 1987. Diatom flora of some sediments from the Indian Ocean Region. In: Atlas of Diatoms Fascicle II. TT maps and publications private limited, 328, GST Road, Chrompet, Madras, pp 1-10.

Estrada, M., Berdalet, E., 1998. Effects of turbulence on phytoplankton. In: Anderson, D.M., Cembella, A.D., Hallegreaff, G.M., (Eds.), Physiological Ecology of Harmful Algal Blooms. Springer-Verlag, Berlin, pp. 601-618.

*Godhe, A., Karunasagar, I., Karunasagar, I., Karlson, B., 2000. Dinoflagellate cysts in recent marine sediments from SW India. Botanica Marina 43, 39-48. 
Godhe, A., Svensson, S., Rehnstam-Holm, A.-S., 2002. Oceanographic settings explain fluctuations in Dinophysis spp. and concentrations of diarrhetic shellfish toxin in the plankton community within a mussel farm area on the Swedish west coast. Marine Ecology Progress Series 240, 71-83.

Goswami, B.N., Venugopal, V., Sengupta, D., Madhusoodanan, M.S., Xavier, P.K., 2006. Increasing trend of extreme rain events over India in a warming environment. Science 314, $1442-1445$.

Hallegraeff, G.A., 1993. A review of harmful algal blooms and their apparent global increase. Phycologia 32, 79-99.

*Hallegraeff, G.M., Bolch, C.J., Blackburn, S.I., Oshima, Y., 1991. Species of the toxigenic dinoflagellate genus Alexandrium in Southeastern Australian waters. Botanica Marina 34, 575-587.

Hansen, P.J., Calado, A.J., 1999. Phagotrophic mechanisms and prey selection in free-living dinoflagellates. Journal of Eukaryotic Microbiology 46, 382-389.

Harland, R., Nordberg, K., Filipsson, H.L., 2006. Dinoflagellate cysts and hydrographical change in Gullmar Fjord, west coast of Sweden. Science of the Total Environment, 355, 204- 231.

*Horner, R.A., 2002. A taxonomic guide to some common marine phytoplankton. Biopress, Bristol, England, UK, pp. 1-195. 
Irigoien, X., Flynn, K.J., Harris, R.P., 2005. Phytoplankton blooms: a 'loophole' in microzooplankton grazing impact? Journal of Plankton Research 27, 313-321.

Jacobsen, D.M., Anderson, D.M., 1986. Growth and grazing rates of Protoperidinium hirobis Abé, a thecate heterotrophic dinoflagellate. Journal of Plankton Research 15, 723-736.

Jost, C., Lawrence, C.A., Campolongo, F., van de Bund, W., Hill, S., DeAngelis, D.L., 2004. The effects of mixotrophy on the stability and dynamics of a simple planktonic food web model. Theoretical Population Biology 66, 37-51.

*Kokinos, J.P., Anderson, D.M., 1995. Morphological development of resting cysts in cultures of the marine dinoflagellate Lingulodinium polyedrum (= L. machaerophorum). Palynology $19,143-166$.

Kovach, W., 1998. Multi-Variate statistical package. Ver.3.01. Pentraeth.

Kremp, A., Anderson, D.M., 2000. Factors regulating germination of resting cysts of the spring bloom dinoflagellate Scrippsiella hangoei from the northern Baltic Sea. Journal of Plankton Research 22, 1311-1327.

*Lewis, J., 1991. Cyst-theca relationships in Scrippsiella (Dinophyceae) and related orthoperidinioid genera. Botanica Marina 34, 91-106. 
*Matsuoka, K., Fukuyo, Y., 2000. Technical guide for modern dinoflagellate cyst study. WESTPAC-HAB/WESTPAC/IOC, Japan Society for the Promotion of Science, Japan, pp. 129.

Matsuoka, K., Cho, H-J., Jacobson, D.M., 2000. Observations of the feeding behavior and growth rates of the heterotrophic dinoflagellate Polykrikos kofoidii (Polykrikaceae Dinophyceae). Phycologia 39, 82-86.

Matsuoka, K., Joyce, L.B., Kotani, Y., Matsuyama, Y., 2003. Modern dinoflagellate cysts in hypertrophic coastal waters of Tokyo Bay, Japan. Journal of Plankton Research 25, 14611470.

Montresor, M., Zingone, A., Sarno, D., 1998. Dinoflagellate cyst production at a coastal Mediterranean site. Journal of Plankton Research 20, 2291-2312.

*Nehring, S., 1997. Dinoflagellate resting cysts from recent German coastal sediments. Botanica Marina 40, 307-324.

Nishitani, G., Yamaguchi, M., Ishikawa, A., Yanagiya, S., Mitsuya, T., Imai, I., 2005. Relationships between occurrences of toxic Dinophysis species (Dinophyceae) and small phytoplanktons in Japanese coastal waters. Harmful Algae 4, 755-762. 
Pertola, S., Faust, M.A., Kuosa, H., 2006. Survey on germination and species composition of dinoflagellates from ballast tanks and recent sediments in ports on the South Coast of Finland, North-Eastern Baltic Sea. Marine Pollution Bulletin 52, 900-911.

Sawant, S.S., Prabhudessai, L., Venkat, K., 2007. Eutrophication status of marine environment of Mumbai and Jawaharlal Nehru Ports. Environmental Monitoring and Assessment 127, 283291.

Setala, O., Autio, R., Kuosa, H., Rintala, J., Ylostalo, P., 2005. Survival and photosynthetic activity of different Dinophysis acuminata populations in the northern Baltic Sea. Harmful Algae 4, 337-350.

Smayda, T.J., Reynolds, C.S., 2001. Community assembly in marine phytoplankton: application of recent models to harmful dinoflagellate blooms. Journal of Plankton Research 23, 447-461.

Smayda, T.J., Reynolds, C.S., 2003. Strategies of marine dinoflagellate survival and some rules of assembly. Journal of Sea Research 49, 95- 106.

Sokal, R.R., Rohlf, F.J., 1981. Biometry, 2nd edition. Freeman WH and Company, San Francisco.

*Sonneman, J. A., Hill, D.R.A., 1997. A taxonomic survey of cyst-producing dinoflagellates from recent sediments of Victorian coastal waters, Australia. Botanica Marina 40, 149-177. 
Subrahmanyan, R., 1946. A systematic account of the marine phytoplankton diatoms of the Madras coast. Proc Ind Acad of Sci. 24, 85-197.

Sullivan, J.M., Swift, E., 2003. Effects of small-scale turbulence on net growth rate and size of ten species of marine dinoflagellates. Journal of Phycology 39, 83-94.

ter Braak, C.J.F., 1995. Ordination. In: Jongman, R.H.G., Ter Braak, C.J.F.,Van Tongeren, O.F.R. (Eds.), Data analysis in community and landscape ecology. Cambridge University Press, Cambridge, pp. 91-173.

*Tomas, C.R., (Ed.). 1997. Identifying Marine Phytoplankton. Academic Press, San Diego, California, pp. 1-858.

*Wall, D., Dale, B., 1968. Modern dinoflagellate cysts and evolution of the Peridiniales. Micropaleontology 14, 265-304.

White, A.W., 1976. Growth inhibition caused by turbulence on the marine dinoflagellate Gonyaulax excavata. Journal of the Fisheries Research Board of Canada 33, 2598-2602.

*Yu-zao, Q., Ying, H., Lei, Z., Kulis, D.M., Anderson, D.M., 1996. Dinoflagellate cysts from recent marine sediments of the South and East China Seas. Asian Marine Biology 13, 87-103.

* These references were used for identification of dinoflagellates (vegetative cells and cysts). 


\section{Legends to Tables}

Table 1 Details of sampling stations in Mumbai and Jawaharlal Nehru Ports, India.

Table 2 Dinoflagellate cysts recorded in Mumbai and Jawaharlal Nehru Ports, India.

Table 3 Vegetative dinoflagellates recorded in surface and near bottom waters in Mumbai and Jawaharlal Nehru Ports, India.

\section{Legends to Figures}

Fig. 1. Location of sampling stations at Mumbai and Jawaharlal Nehru Ports, India.

Fig. 2 (1-25). Dinoflagellate cysts from Mumbai and Jawaharlal Nehru Ports, India. Cyst dimensions (length and width of cyst body, and length of spines in $\mu \mathrm{m}$ ) are indicated in brackets after the species name.

Gonyaulacoid cysts -(1) Alexandrium cf. tamarense $(45.6 \mu \mathrm{m} \times 25.65 \mu \mathrm{m})$. (2) Gonyaulax scrippsae $(34.2 \mu \mathrm{m} ; 11.4 \mu \mathrm{m})$. (3) Gonyaulax spinifera $(45.6 \mu \mathrm{m} ; 11.4 \mu \mathrm{m})$. (4) Pyrodinium cf.

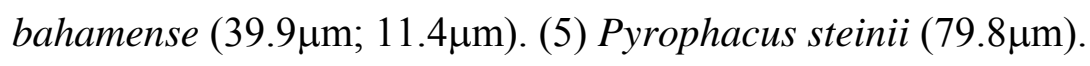

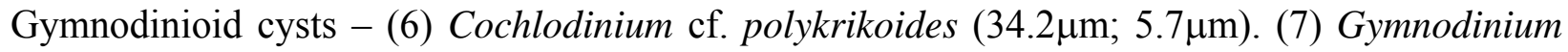
cf. catenatum - germinated cyst $(42.75 \mu \mathrm{m})$. (8) Pheopolykrikos hartmannii $(45.6 \mu \mathrm{m} ; 8.55 \mu \mathrm{m})$.

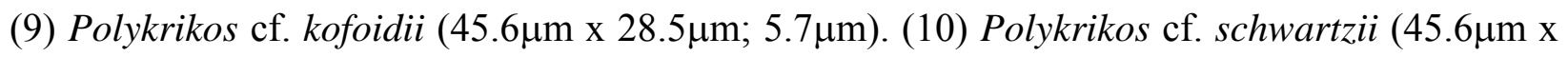
$34.2 \mu \mathrm{m})$. 
Peridinioid cysts - (11) Protoperidinium claudicans $(57 \mu \mathrm{m}$ x $57 \mu \mathrm{m} ; 2.85 \mu \mathrm{m})$. (12a) Protoperidinium conicum $(57 \mu \mathrm{m}$ x $34.2 \mu \mathrm{m} ; 11.4 \mu \mathrm{m})$. (12b) Protoperidinium conicum $(34.2 \mu \mathrm{m}$ x

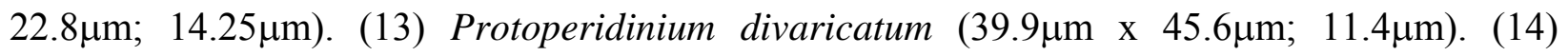

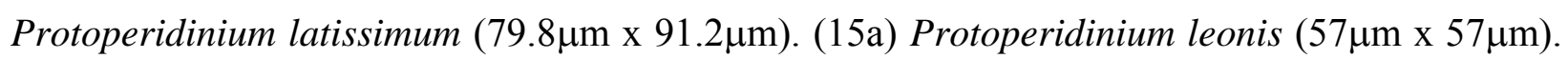
(15b) Protoperidinium leonis - germinated cyst $(74.1 \mu \mathrm{m}$ x $79.8 \mu \mathrm{m})$. (16) Protoperidinium cf.

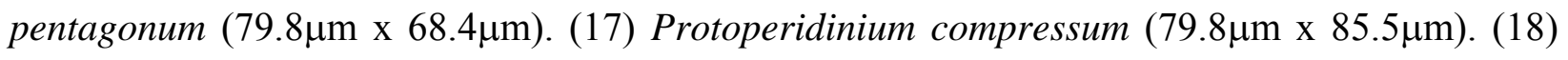
Protoperidinium sp. (Stelladinium robustum) $(96.9 \mu \mathrm{m}$ x $91.2 \mu \mathrm{m})$. (19) Protoperidinium subinerme $(57 \mu \mathrm{m} \times 45.6 \mu \mathrm{m})$. (20a) Scrippsiella trochoidea $(45.6 \mu \mathrm{m} \times 39.9 \mu \mathrm{m} ; 5.7 \mu \mathrm{m}) .(20 \mathrm{~b})$

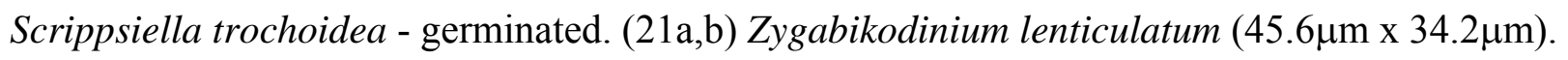

Fig. 3. Spatial variation in abundance of vegetative dinoflagellates (cells $\mathrm{L}^{-1}$ ) in (a-c) surface and (d-f) near bottom waters and (g-i) dinoflagellate cyst abundance (cysts $\mathrm{g}^{-1}$ dry sediment) in sediment in Mumbai and Jawaharlal Nehru Ports, India.

Nos. 1-30 indicate the stations where sampling was carried out.

(PM-I) Post-monsoon I, (PreM) Pre-monsoon, (PM-II) Post-monsoon II.

Fig. 4. Non-metric multidimensional (NMDS) scaling ordination based on the Bray-Curtis similarity coefficient of vegetative dinoflagellates in (a-c) surface and (d-f) near bottom waters and (g-i) dinoflagellate cyst abundance in sediment in Mumbai and Jawaharlal Nehru Ports, India. Stations enclosed within the dotted lines are similar at 50\% Bray-Curtis similarity coefficient.

(PM-I) Post-monsoon I, (PreM) Pre-monsoon, (PM-II) Post-monsoon II. 
Fig. 5. Dinoflagellate community composition based on nutrition in the vegetative state and contribution of dinoflagellate groups $(\%)$ to the dinoflagellate community in surface waters, near bottom waters and sediment in Mumbai and Jawaharlal Nehru Ports, India.

(PM-I) Post-monsoon I, (PreM) Pre-monsoon, (PM-II) Post-monsoon II.

The maximum symbol diameter corresponds to $66.92 \%$.

Fig. 6. Schematic representation of the seasonal modulations in the pelagic and benthic stages of dinoflagellates in Mumbai and Jawaharlal Nehru Ports, India during post-monsoon I, premonsoon and post-monsoon II.

Fig. 7. Ordination diagrams for species and stations based on Canonical Correpondence Analysis (CCA) of the vegetative and cyst communities of dinoflagellates. The environmental variables (temperature, salinity, SPM, nitrate, nitrite, phosphate, oxygen saturation percentage, sand $\%$, silt $\%$, clay $\%$ and organic carbon) are indicated by arrows, labeled Temp, Sal, SPM, NO3, NO2, PO4, OSat $\%$, Sand\%, Silt\%, Clay\% and OrgC respectively. Station codes are given in Table 1, species codes are presented in Tables 2 and 3. General grouping of species and stations are indicated. See text for interpretation of ordination diagrams.

(PM-I) Post-monsoon I, (PreM) Pre-monsoon, (PM-II) Post-monsoon II.

Fig. 8. South West monsoon pattern in Mumbai and Jawaharlal Nehru Ports. Arrows indicate sampling periods.

(PM-I) Post-monsoon I, (PreM) Pre-monsoon, (PM-II) Post-monsoon II. 

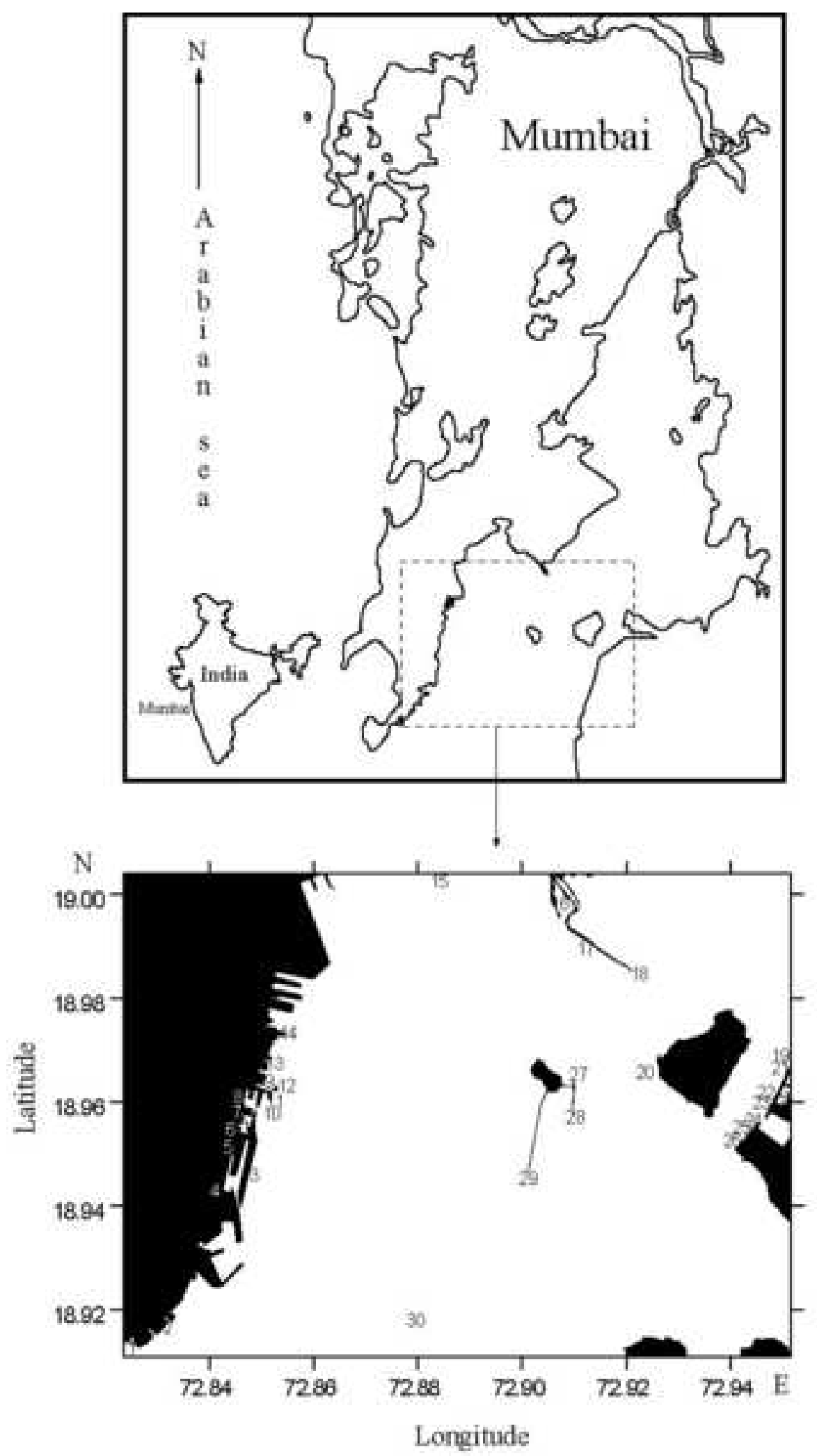

Fig. 1 


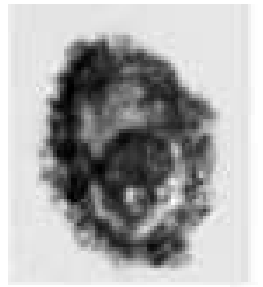

1

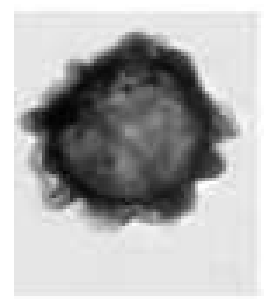

6

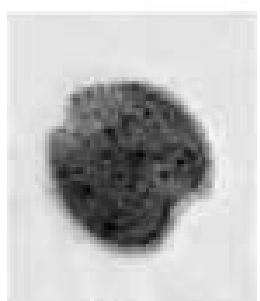

11

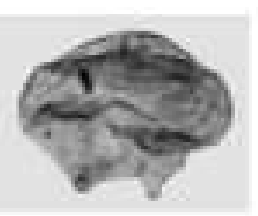

$15 \mathrm{a}$

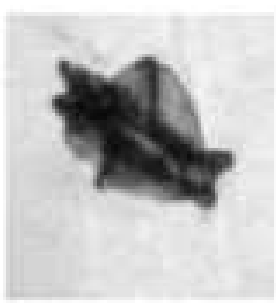

19

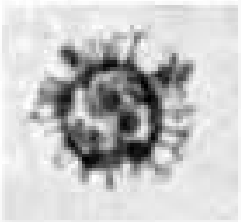

2

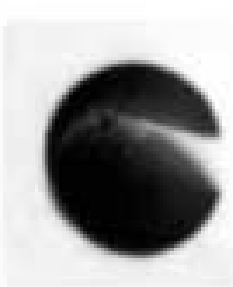

7

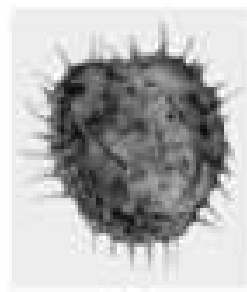

$12 \mathrm{a}$

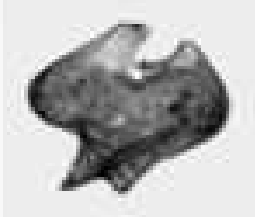

$15 b$

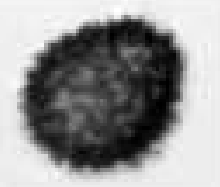

20a

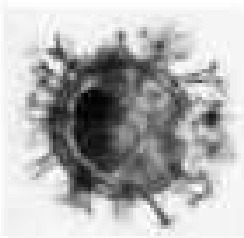

3

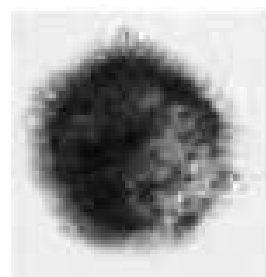

8

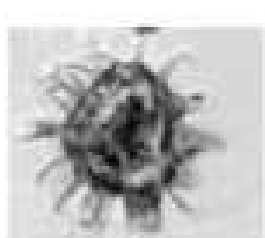

$12 \mathrm{~b}$

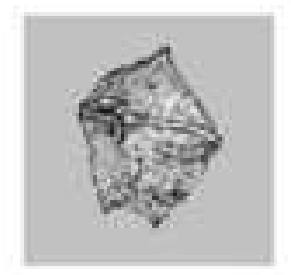

16

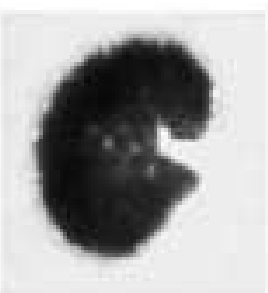

$20 \mathrm{~b}$

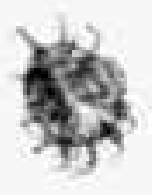

4

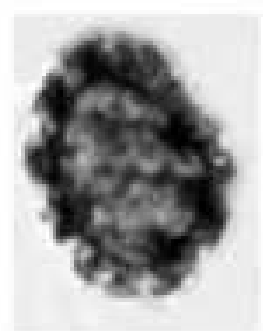

9

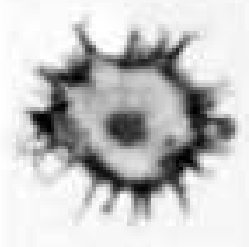

13

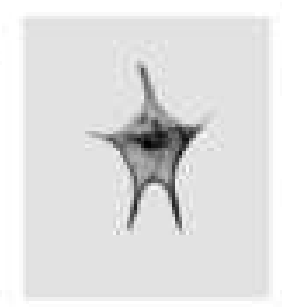

17
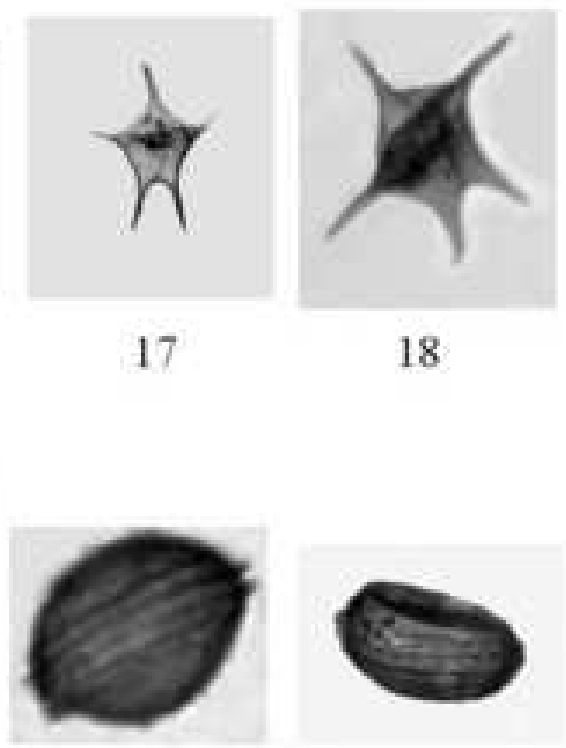

$21 \mathrm{a}$
18

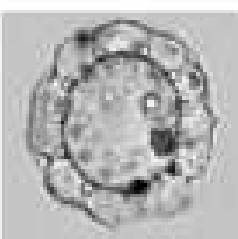

5
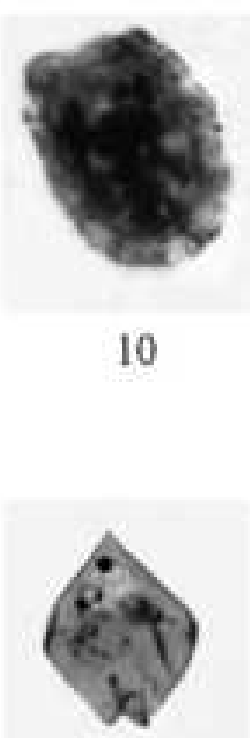

14

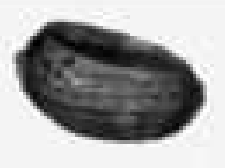

$21 \mathrm{~b}$

Fig. 2 

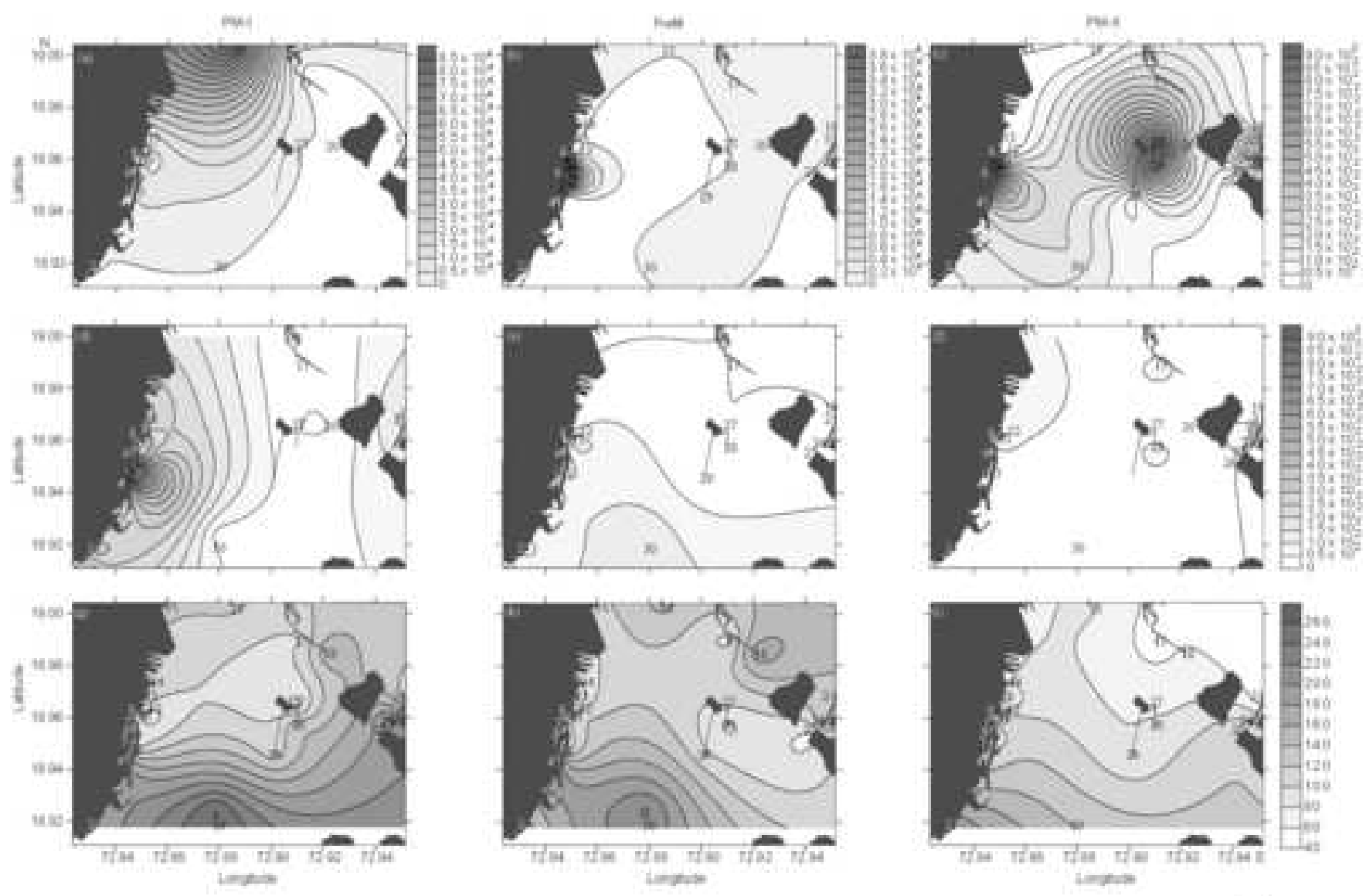
PQM.!
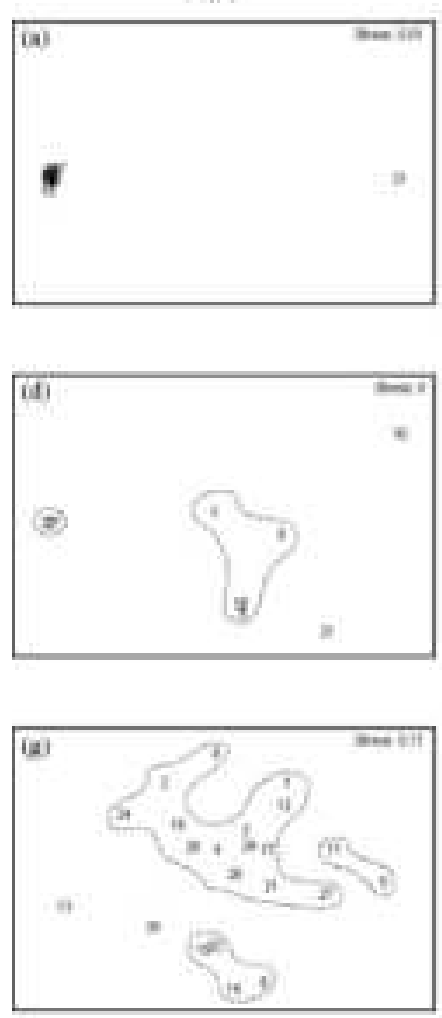
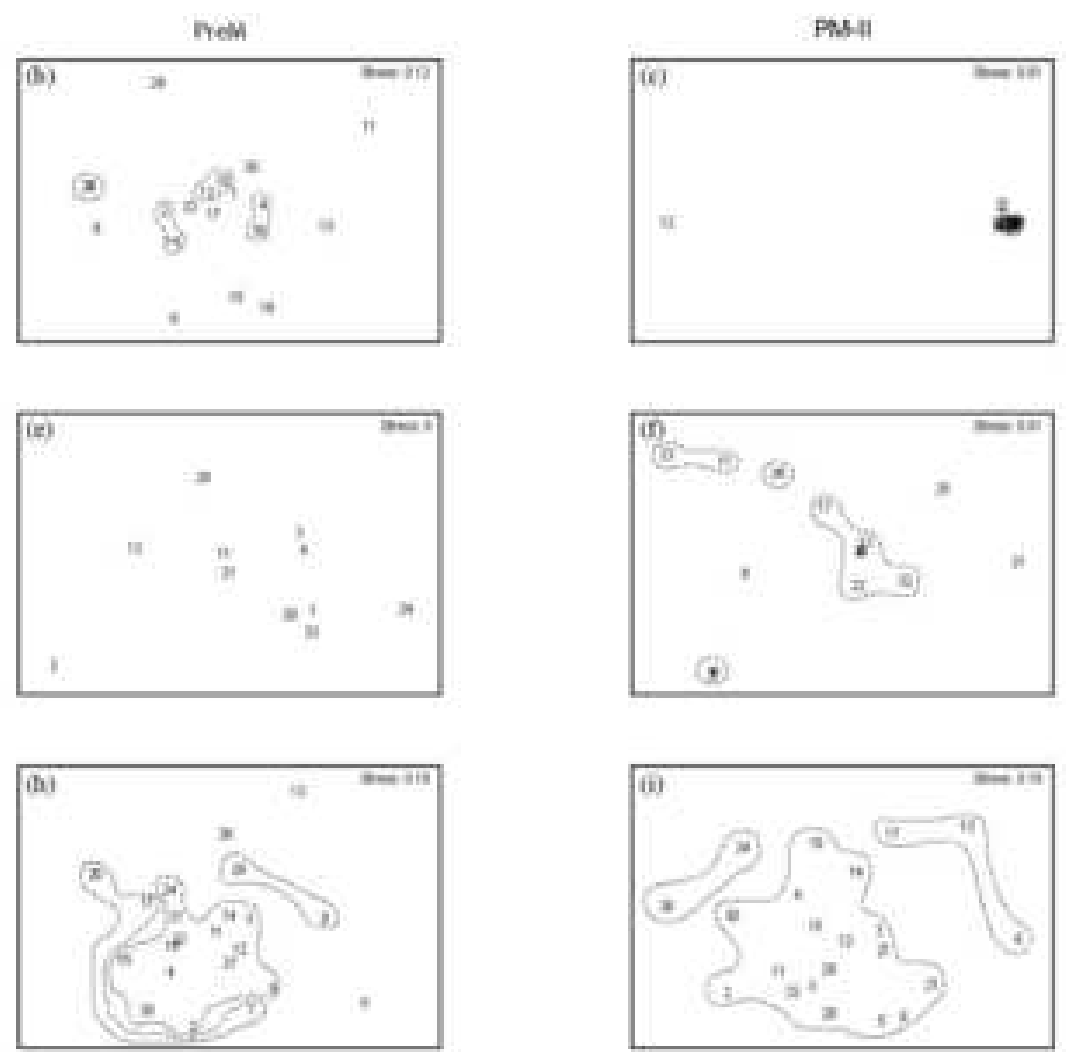

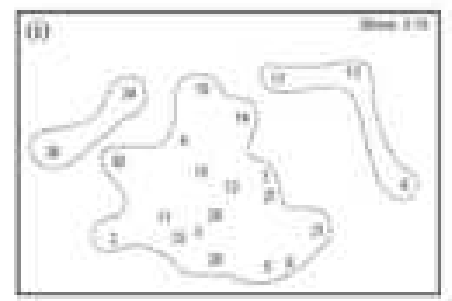

Fig. 4 

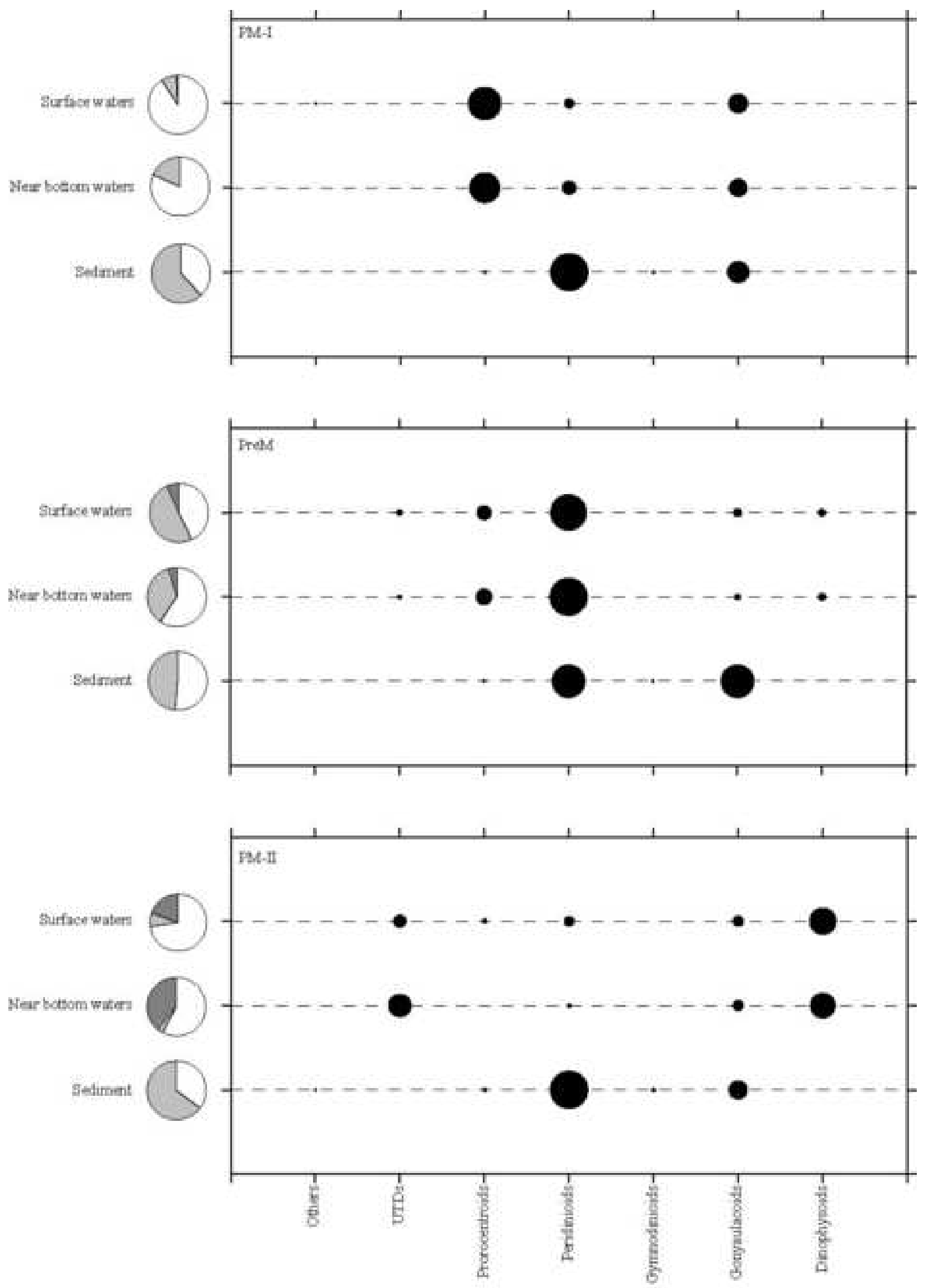

Autotrophic $\square$ Heterotrophic $\square$ UTDs

Fig 5 


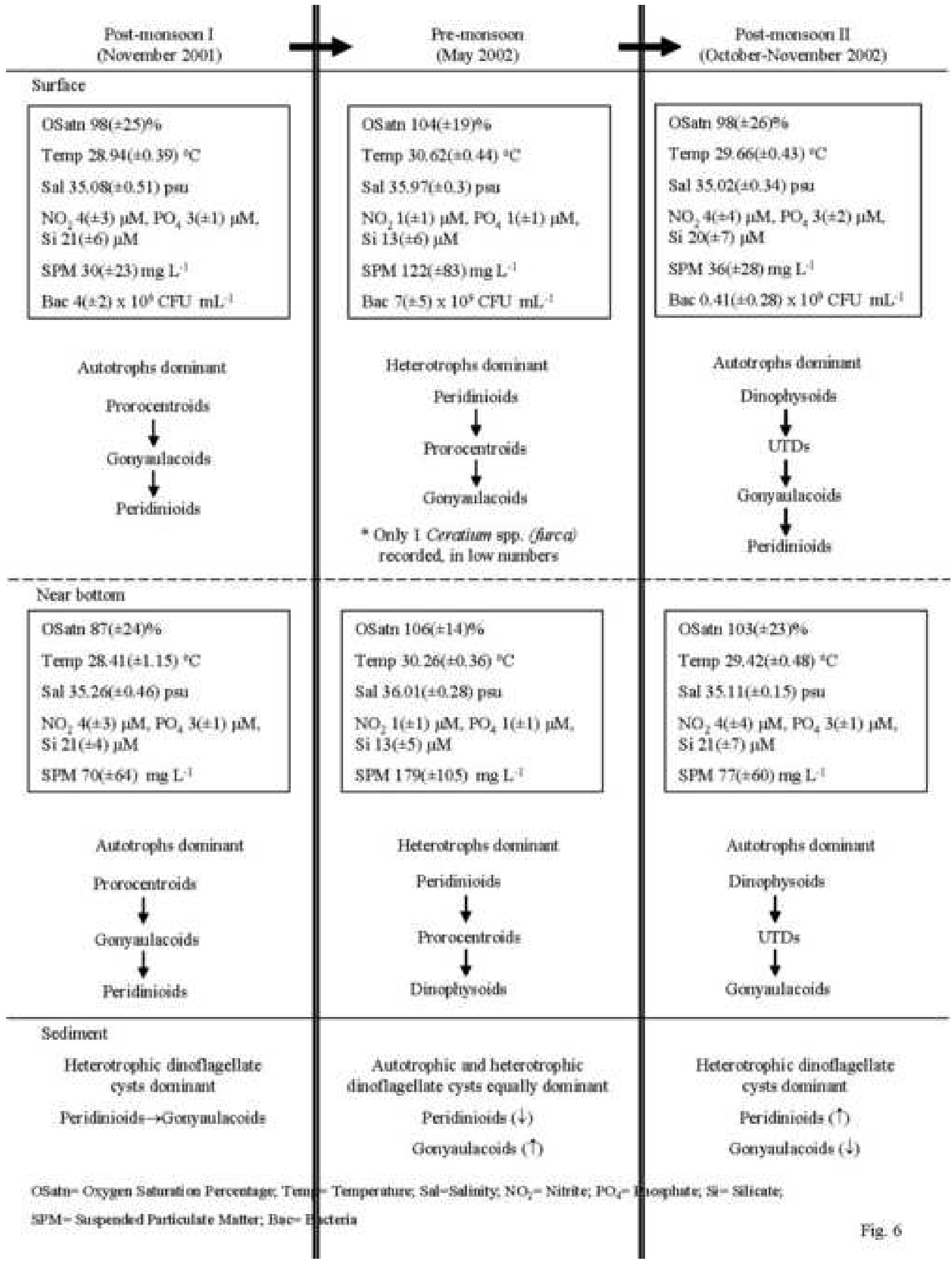


Species biplot
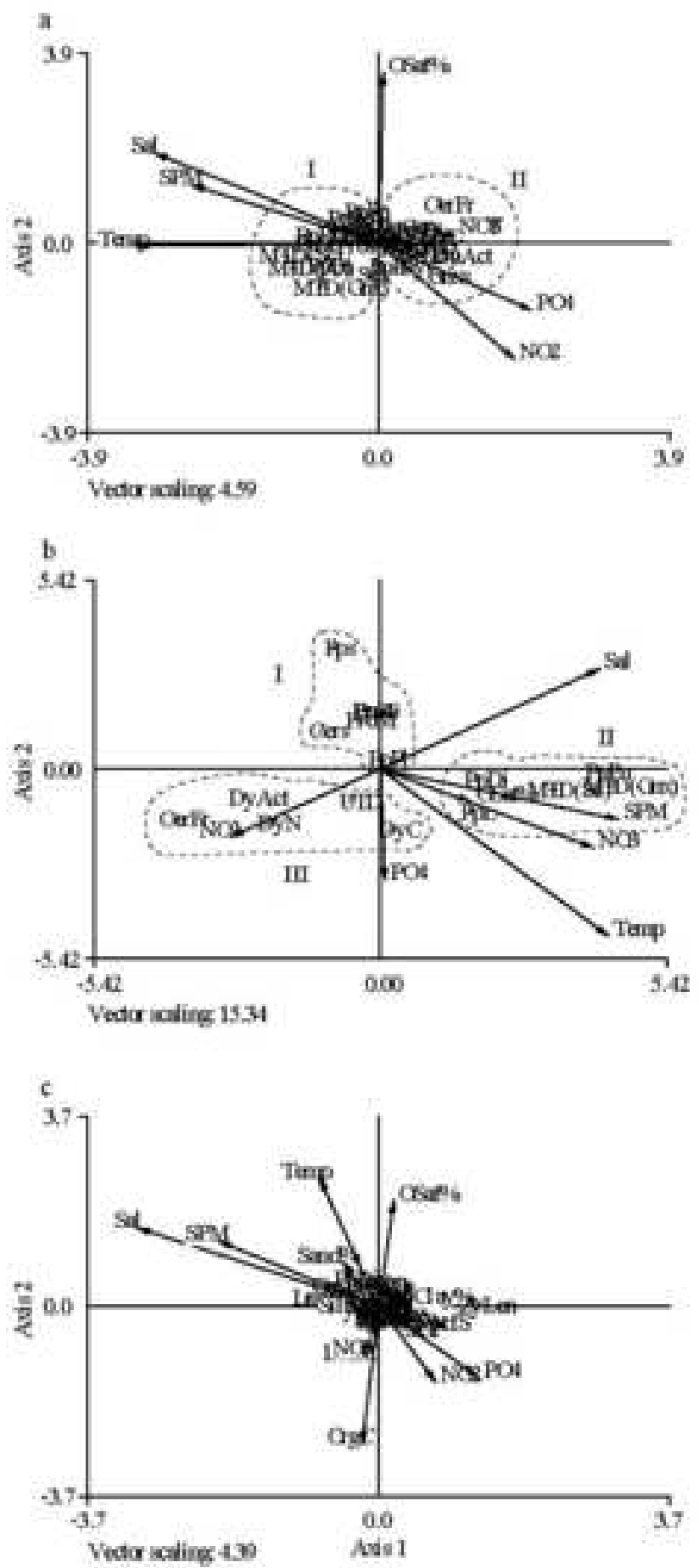

Satien bipl of
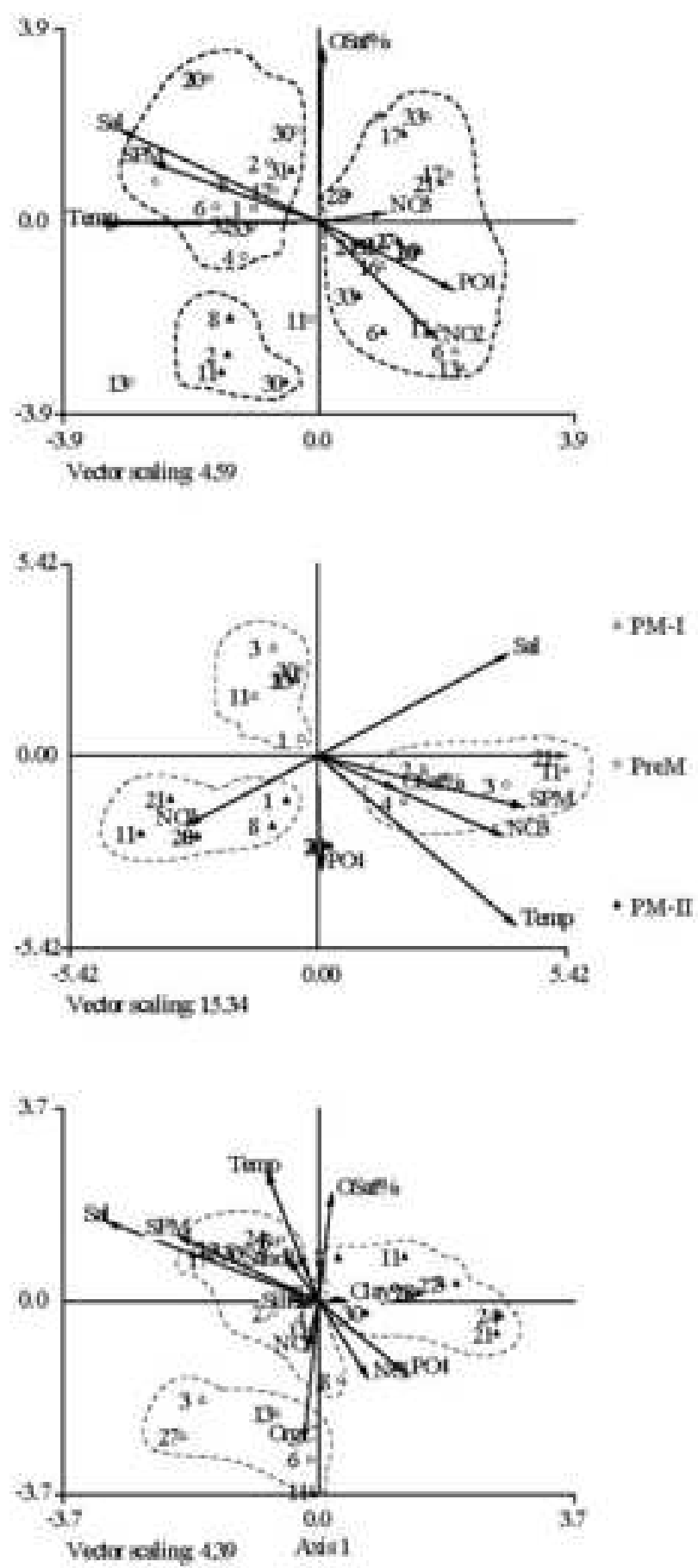

Fig. 7 


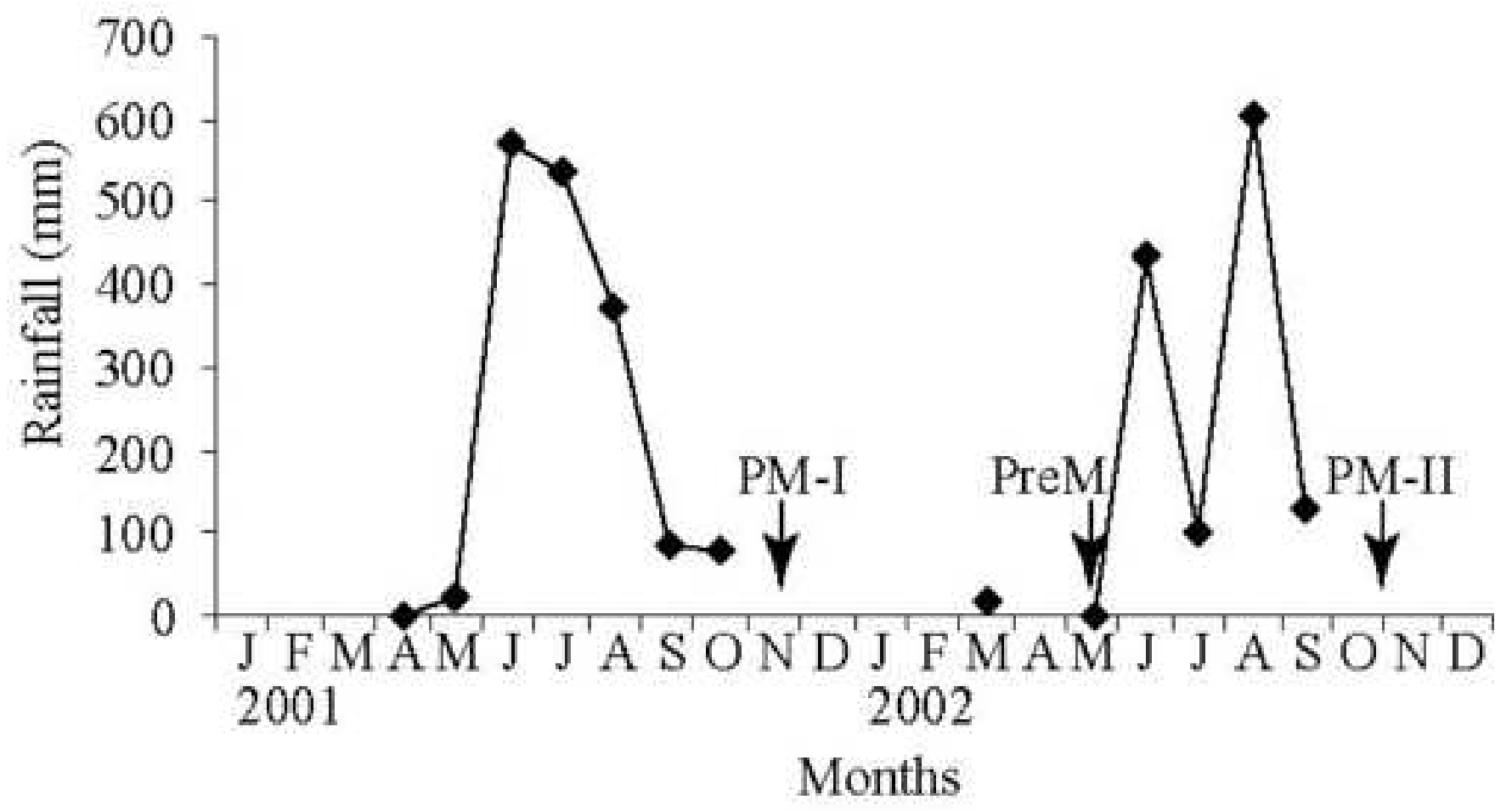

Fig. 8 
Table 1

\begin{tabular}{|c|c|c|c|}
\hline Station code & Station name & Depth $(\mathrm{m})^{*}$ & Sediment texture \\
\hline 1 & Sasoon Dock & 6 & silt-clay \\
\hline 2 & Apollo Bandar & 6 & clay \\
\hline 3 & Harbour Wall Berth 20 & 9 & silt \\
\hline 4 & Indira Dock $1^{*}$ & 10 & silt \\
\hline 5 & Indira Dock $2 *$ & 10 & silt \\
\hline 6 & Victoria Dock 1 & 8 & silt-clay \\
\hline 7 & Victoria Dock 2 & 9 & silt-clay \\
\hline 8 & Princess Dock 1 & 6 & silt \\
\hline 9 & Princess Dock 2 & 6 & silt \\
\hline 10 & Princess Dock 3 & 8 & clay \\
\hline 11 & Ferry Wharf 1 & 6 & clay \\
\hline 12 & Ferry Wharf 2 & 6 & clay \\
\hline 13 & Kasara Basin & 3 & silt-clay \\
\hline 14 & Break Yard & 3 & silt \\
\hline 15 & Mahul Creek & 3 & clay \\
\hline 16 & Old PirPau 1 & 10 & silt \\
\hline 17 & New Pirpau 1 & 8 & silt \\
\hline 18 & New Pirpau 2 & 11 & clay \\
\hline 19 & JNPT Marker Buoy & 12 & silt-clay \\
\hline 20 & Elephanta 1 & 11 & silt-clay \\
\hline 21 & JNPT Container Berth 1 & 14 & silt-clay \\
\hline 22 & JNPT Container Berth 2 & 16 & silt-clay \\
\hline 23 & JNPT Container Berth 3 & 11 & silt \\
\hline 24 & JNPT Bulk Berth 1 & 10 & silt \\
\hline 25 & JNPT Bulk Berth 2 & 12 & silt \\
\hline 26 & JNPT Bulk Berth 3 & 11 & silt \\
\hline 27 & Jawahar Dweep Berth 1 & 11 & clay \\
\hline 28 & Jawahar Dweep Berth 3 & 10 & silt-clay \\
\hline 29 & Jawahar Dweep Berth 4 & 13 & silt-clay \\
\hline 30 & Mumbai Channel Marker Buoy & 11 & silt-clay \\
\hline 31 & Spoil Ground Ebb & 12 & silt-clay \\
\hline 32 & Spoil Ground Flood & 18 & silt-clay \\
\hline 33 & Control & 14 & silt \\
\hline
\end{tabular}

JNPT: Jawaharlal Nehru Port Trust, * Depth varies with tide 
Table 2

\begin{tabular}{|c|c|c|c|c|}
\hline Species & Species code & PM-I & PreM & PM-II \\
\hline \multicolumn{5}{|l|}{ Autotrophic } \\
\hline Alexandrium cf. affine (Inoue et Fukuyo) Balech & AxA & & * & \\
\hline Alexandrium cf. minutum Halim & $\mathrm{AxM}$ & & & $*$ \\
\hline Alexandrium cf. tamarense (Lebour) Balech & AxT & * & & \\
\hline Cochlodinium polykrikoides Margalef & CocP & $*$ & & \\
\hline Gonyaulax digitalis (Pouchet) Kofoid & GnxD & * & * & $*$ \\
\hline Gonyaulax scrippsae Kofoid & GnxS & * & $*$ & $*$ \\
\hline Gonyaulax spinifera (Claparède et Lachmann) complex & GnxSp & * & $*$ & $*$ \\
\hline Gymnodinium cf. catenatum Graham & GymC & & & $*$ \\
\hline Lingulodinium polyedrum (Stein) Dodge & LngP & * & $*$ & $*$ \\
\hline Pentapharsodinium dalei Indelicato et Loeblich & PenD & & * & $*$ \\
\hline Pheopolykrikos hartmannii (Zimmermann) Matsuoka et Fukuyo & $\mathrm{PheH}$ & * & & \\
\hline Protoceratium reticulatum (Clapàrede et Lachmann) Bütschli & PcerR & * & $*$ & $*$ \\
\hline Pyrodinium cf. bahamense (Böhm) Steidinger & PyrBah & $*$ & $*$ & \\
\hline Pyrophacus steinii (Schiller) Wall et Dale & PyhS & $*$ & $*$ & $*$ \\
\hline Scrippsiella trochoidea (Stein) Loeblich III & $\mathrm{ScT}$ & * & $*$ & $*$ \\
\hline \multicolumn{5}{|l|}{ Heterotrophic } \\
\hline Diplopsalis lenticula Bergh & DipL & * & & \\
\hline Lebouraia cf. minuta Abé & LebM & * & $*$ & $*$ \\
\hline Polykrikos cf. kofoidii Chatton & PoK & $*$ & $*$ & $*$ \\
\hline Polykrikos cf. schwartzii Bütschli & $\mathrm{PoS}$ & & * & $*$ \\
\hline Protoperidinium claudicans Paulsen & PpCla & * & $*$ & $*$ \\
\hline Protoperidinium compressum (Abé) Balech & PpCom & & $*$ & $*$ \\
\hline Protoperidinium conicoides Paulsen & PpCds & * & * & * \\
\hline Protoperidinium conicum (Gran) Balech & $\mathrm{PpC}$ & * & * & $*$ \\
\hline Protoperidinium divaricatum (Meunier) Balech & PpDiv & * & * & $*$ \\
\hline Protoperidinium latissimum (Kofoid) Balech & PpLa & * & * & $*$ \\
\hline Protoperidinium leonis (Pavillard) Balech & $\mathrm{PpL}$ & * & * & * \\
\hline Protoperidinium pentagonum (Gran) Balech & PpPn & * & $*$ & $*$ \\
\hline Protoperidinium cf. pentagonum Gran & PpcfP & * & * & $*$ \\
\hline Protoperidinium subinerme (Paulsen) & $\mathrm{PpSu}$ & * & * & $*$ \\
\hline Protoperidinium sp. (Stelladinium robustum Zonneveld) & PpcfS & & * & * \\
\hline Protoperidinium sp. (Trinovantedinium palidifluvum Matsuoka) & PpsT & & & * \\
\hline Protoperidinium sp. & Pps & * & $*$ & $*$ \\
\hline Zygabikodinium lenticulatum (Paulsen) Loeblich et Loeblich & ZyLen & & * & $*$ \\
\hline
\end{tabular}

PM-I, PreM, PM-II represent post-monsoon I, pre-monsoon and post-monsoon II sampling periods respectively, * indicates presence during particular sampling periods 
Table 3

\begin{tabular}{|c|c|c|c|c|c|c|c|}
\hline Species & Species code & $\mathrm{PM}-\mathrm{I}_{\mathrm{su}}$ & $P M-I_{n b}$ & PreM $_{\mathrm{su}}$ & $\operatorname{PreM}_{\mathrm{nb}}$ & $\mathrm{PM}-\mathrm{II}_{\mathrm{su}}$ & $\mathrm{PM}-\mathrm{II}_{\mathrm{nb}}$ \\
\hline \multicolumn{8}{|l|}{ Autotrophic } \\
\hline Alexandrium insuetum Balech & AxI & & & & & * & \\
\hline Alexandrium sp. & Axs & & & & & & * \\
\hline Ceratium furca (Ehrenberg) Claparède \& & CerFr & & & & & & \\
\hline Lachmann & & * & * & * & & * & * \\
\hline Ceratium fusus (Ehrenberg) Dujardin & CerFs & * & & & & * & \\
\hline Ceratium kofoidii Jørgensen & CerK & $*$ & & & & & \\
\hline Ceratium lineatum (Ehrenberg) Cleve & CerL & * & & & & & \\
\hline Ceratium sp. & Cers & $*$ & * & & & & \\
\hline Dinophysis acuta Ehrenberg & DyAct & & & & & $*$ & $*$ \\
\hline Dinophysis caudata Saville-Kent & DyC & & & & * & * & * \\
\hline Dinophysis norvegica Claparède \& & DyN & & & & & & \\
\hline Lachmann & & & & * & & * & * \\
\hline Dinophysis sp. & Dys & & & * & & & \\
\hline Dissodium asymmetricum (Mangin) & DisA & & & & & & \\
\hline Loeblich & & & & * & * & & \\
\hline Gonyaulax sp. & Gnxs & * & & * & & & \\
\hline $\begin{array}{l}\text { Prorocentrum compressum (Bailey) Abé ex } \\
\text { Dodge }\end{array}$ & ProC & & & & & * & \\
\hline Prorocentrum emarginatum Fukuyo & ProE & & & * & & & \\
\hline Prorocentrum gracile Schütt & ProG & & & * & * & * & \\
\hline Prorocentrum micans Ehrenberg & ProM & * & * & * & * & * & \\
\hline Prorocentrum sp. & Pros & & & * & * & & \\
\hline Pyrocystis robusta Kofoid & PysR & & & & & & * \\
\hline Pyrophacus steinii (Schiller) Wall \& Dale & PyhS & & & & & * & \\
\hline Scrippsiella trochoidea (Stein) Loeblich III & $\mathrm{ScT}$ & * & * & & & * & \\
\hline Scrippsiella spp. & Scs & * & & * & & * & \\
\hline Minute thecate dinoflagellate (Alexandrium) & $\operatorname{MTD}(\mathrm{Ax})$ & & & * & & * & \\
\hline Minute thecate dinoflagellate (Gonyaulax) & $\operatorname{MTD}(\mathrm{Gnx})$ & & & $*$ & * & * & \\
\hline Minute thecate dinoflagellate (Scrippsiella) & $\operatorname{MTD}(\mathrm{Sc})$ & & & * & * & & \\
\hline \multicolumn{8}{|l|}{ Heterotrophic } \\
\hline Gotoius abei Matsuoka & GotA & & & * & & * & \\
\hline Protoperidinium conicum (Gran) Balech & $\mathrm{PpC}$ & & & $*$ & & * & \\
\hline Protoperidinium divergens (Ehrenberg) & $\mathrm{PpDi}$ & & & & & & \\
\hline Balech & & & & * & * & & \\
\hline Protoperidinium leonis (Pavillard) Balech & $\mathrm{PpL}$ & & & & * & & \\
\hline Protoperidinium oblongum (Aurivillius) & $\mathrm{PpOb}$ & & & & & & \\
\hline Parke \& Dodge & & & & * & & & \\
\hline Protoperidinium pedunculatum (Schütt) & PpPd & & & & & & \\
\hline Balech & & & & * & * & & \\
\hline Protoperidinium pellucidum Bergh & $\mathrm{PpPl}$ & & & $*$ & $*$ & $*$ & \\
\hline Protoperidinium pentagonum (Gran) Balech & PpPn & & & $*$ & * & & \\
\hline Protoperidinium cf. pentagonum Gran & PpcfP & & & & & $*$ & \\
\hline Protoperidinium steinii (Jørgensen) Balech & PpSt & * & & $*$ & * & * & \\
\hline Protoperidinium subinerme (Paulsen) & $\mathrm{PpSu}$ & & & & & & \\
\hline Loeblich III & & & & * & & & \\
\hline Protoperidinium spp. & Pps & * & $*$ & $*$ & & * & $*$ \\
\hline \multicolumn{8}{|l|}{ Others } \\
\hline Unidentified globular dinoflagellate & $\mathrm{UDi}(\mathrm{g})$ & & & * & & & \\
\hline Unidentified tiny dinoflagellate & UTD & & & * & $*$ & $*$ & * \\
\hline
\end{tabular}

PM-I, PreM, PM-II represent post-monsoon I, pre-monsoon and post-monsoon II sampling periods respectively, su - surface, nb near bottom, * indicates presence during particular sampling periods 